DOI: https://doi.org/10.32839/2304-5809/2019-1-65-102

UDC 330.3

\author{
Holovchuk Kateryna, Dierbunova Karyna, Shevcheko Yuliia
} National Aviation University

\title{
DEVELOPMENT OF UNCERTAINITY ACCOUNTING METHODS (H-MODELS)
}

\begin{abstract}
Summary. The need to form a specific method for estimating the value of investment projects, taking into account the high volatility of external and internal factors of its implementation is now becoming urgent due to the transition of the international investment market from extensive to intensive development and the appearance of corresponding challenges to the Ukrainian investment market related to its credibility and transparency in the eyes of foreign institutional investors. The relevance of the chosen topic on the one hand is due to the presence of controversial issues in theory and methodology and on the other hand due to the insufficient development of the methodology and technique for estimating the value of investment projects. The article indicates the main drawbacks of the existing methods of taking risks and uncertainties into account in the implementation of investment projects and suggests an original method based on the principles of the theory of fuzzy sets and interval computing technology. Using the proposed method in assessing the value of investment projects allows you to take into account the impact of increased risk and uncertainty factors of its implementation, which ultimately increases the reliability of the results obtained during the assessment for all participants in the investment process.
\end{abstract}

Keywords: investment project, uncertainty, H-model, risk, interval values.

Головчук К.О., Дербунова К.І., Шевченко Ю.В. Національний авіаційний університет

\section{РОЗВИТОК МЕТОДІВ ВРАХУВАННЯ НЕВИЗНАЧЕНОСТІ (Н-МОДЕЛЕЙ)}

\begin{abstract}
Анотація. Необхідність формування специфічного методу оцінки вартості інвестиційних проектів з урахуванням високої волатильності зовнішніх та внутрішніх фракторів його реалізації стає актуальною через перехід міжнародного інвестиційного ринку з екстенсивного на інтенсивний розвиток і поява відповідних викликів українському інвестиційному ринку, пов'язаних з його довірою та прозорістю в очах іноземних інституційних інвесторів. Актуальність обраної теми, з одного боку, обумовлена наявністю суперечливих питань у теорії та методології, а з іншого боку, через недостатню розробку методології та методики оцінки вартості інвестиційних проектів. У статті наведені основні недоліки існуючих методів врахування ризиків та невизначеностей при реалізації інвестиційних проектів та запропоновано оригінальний метод, заснований на принципах теорії нечітких множин та технології інтервальних обчислень. Використання запропонованого методу при оцінщі вартості інвестиційних проектів дозволяе враховувати вплив підвищеного ризику і невизначеність факторів його реалізащії, що в кінцевому підсумку підвищуе достовірність отриманих результатів при оцінці для всіх учасників інвестиційного процесу.
\end{abstract}

Ключові слова: інвестиційний проект, невизначеність, Н-модель, ризик, значення інтервалу.

$\mathrm{F}$ ormulation of the problem. The investment project is developed based on well-defined assumptions regarding capital and operating costs, sales of manufactured products, prices for goods, the project time frame. Regardless of the quality and validity of these assumptions the future development of events associated with the implementation of the project is always ambiguous. This is the main axiom of any business activity. In this regard the practice of investment design considers among others aspects of uncertainty and risk.

Recent research and publications analysis. An unconventional approach is a new theory and technology for the effective solution of problems of accounting for uncertainty, developed by A.S. Narinyani, V.G. Napreenko, known as the technology of under-defined calculations (H-calculations) and under-defined models (H-models).

Identification of previously unsettled parts of the general problem. H-models approach refers to the direction of constraint programming, which has recently been actively developed in the world as one of the most promising for models with a large number of undetermined factors. Due with this choice of research topic and its target orientation are sufficiently relevant.
The purpose of the article. The main purpose of article is to define an effective solution of problems of accounting for uncertainty and to define solutions for predicting the basic values and indicators of the development of an enterprise including the implementation of an investment project.

Main material presentation. Uncertainty refers to the state of ambiguity in the development of certain events in the future the state of ignorance and the impossibility of accurately predicting the basic values and indicators of the development of an enterprise including the implementation of an investment project.

It is also recommended to take into account risk in efficiency calculations the possibility of such conditions that will lead to negative consequences for all or individual project participants. In general, risk refers to the possibility that an undesirable event will occur. In business, it is customary to equate risk with the possibility of an enterprise losing some of its resources, reducing planned revenues or creating additional expenses as a result of certain production and financial activities.

The methods of accounting for uncertainty generally accepted in practice are reduced to sensitivity analysis and scenario approach. However, they carry an internal contradiction consisting in the 
fact that undefined (underdetermined in essence) indicators are described by deterministic values.

In addition, the following features are typical of traditional mathematical models used in investment design:

- algorithmicity. The model developer must form a model algorithm - determine the sequence of calculations in accordance with which the model should work;

- target character. The model is intended to solve a specific problem, and a change in the modeling problem usually leads to a change in the model;

- determinism of the values of indicators - usually the ideal solution is considered, in which all indicators are precisely defined;

- the determinism of the system of mathematical dependencies - a "correct" model is considered to contain dependencies that ensure the unambiguity of the exact solution that is, such a model that cannot be either underdetermined or redefined;

- division of all indicators into "input" (arguments) and "output" (functions).

All these features of the traditional approach complicate the development of models and limit the possibilities of their practical use.

Currently, the use of H-models has been successfully tested on solving practical problems of modeling the development of national and regional economies the functioning of enterprises and the evaluation of investment projects.

In comparison with traditional investment design tools the H-model technology provides a large number of additional features useful for investment design:

- the ability to calculate using interval estimates of indicators (along with accurate estimates);

- the ability to calculate in case of absence of part of the parameters and in the presence of rough estimates of the parameters;

- the ability to control risk, assess the quality of information used, identify and eliminate the causes of excessive underdetermination;

- the ability to solve ambiguous tasks;

- the ability to set the desired values of the resulting indicators;

- the ability to analyze a large number of project options without busting them;

- the ability "not to miss" any decision;

- simplified project support.

Let us consider in more detail each of these possibilities.

Ability to calculate using interval estimates of indicators (along with accurate estimates). Interval estimates provide a very visual expression of the undeterminedness of the original and resulting data. As an example in fig. 1 shows the results of forecasting the flow of investment and operating activities for one of the investment projects studied. Narrow line 1 in the graphs shows the results of non-interval calculation with average predicted values of price indicators (prices for products, materials, energy and labor remuneration rates), a wide area 2 - results of interval calculations with price variation deviations of $3 \%$ per year for product prices and by $1 \%$ per year - by other indicators. The graphs clearly show the increase in time of the uncertainty of the forecast, reflecting the above-noted feature of a nonstationary economy "the final horizon of reliable visibility".
Current undiscounted cash flow from operating and investing activities

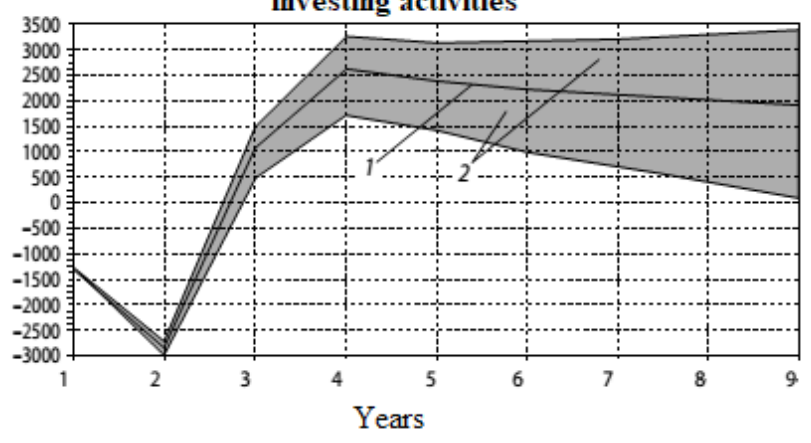

Accumulated undiscounted cash flow from operating and investing activities

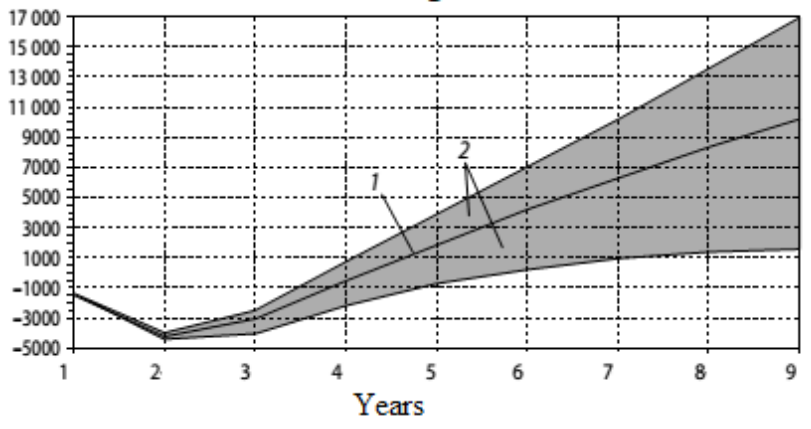

Fig. 1. Project cash flow forecast, million USD (1 - deterministic calculation by average values, 2 - updated calculation using the H-model)

Source: developed by the author according to the data [3]

The ability to calculate in case of absence of part of the parameters and in the presence of rough estimates of the parameters. The ability of $\mathrm{N}$-models to give a solution with incomplete and inaccurate information about simulated indicators is the most important of the advantages of the technology under consideration.

Select the following stages and stages of development of the investment project:

Pre-investment stage 1 . The project implementation period, the total output in physical terms, investment and operating standards per unit of output, the price of products and the rate on possible loans are determined. All indicators are approximate and are described by intervals;

Pre-investment stage 2. The schedule of capital investments and sales of products by the project year is specified;

Pre-investment stage 3. Structuring the project and organizing financing. The schedule for obtaining and repaying loans;

Stage 4. Final refinement of project parameters.

At all the mentioned stages (except the last one) there is no part of the project's essential indicators. For example, before stage 3, the schedule for receiving and repaying loans is unknown. Nevertheless, at all these stages, the H-model allows building estimates of project indicators. As the information taken into account becomes more complete, the estimates are refined. As a typical example, let us indicate the following calculated values of the accumulated balance of operational, investment and financial flows, expressed in shares of the final deci- 
sion: stage 1 - from 43 to $154 \%$, stage 2 - from 66 to $136 \%$, stage 3 - from 71 to $84 \%$, stage $4-100 \%$.

Ability to control risk, assessing the quality of the information used, identify and eliminate the causes of excessive underdetermination. When using $\mathrm{H}$-models, the width of the intervals of the initial and resulting data of the investment project becomes a convenient measure of forecast risk (at the same time, you can use ordinary risk indicators, such as risk capital, for example). Since the new information entered into the calculation clarifies (narrows) the intervals of indicators, the magnitude of this clarification can serve as an indicator of the value of information: the absence of a narrowing indicates the uselessness of information, and a significant clarification of the intervals indicates the value of information. Thus, the quality of the information used in the calculations is objectively evaluated.

The ability to solve ambiguous tasks. Achieving a given amount of profit is an ambiguous task, because within the same project, the desired profit can be obtained in different ways. For ordinary mathematics, ambiguity is an extremely difficult problem. For H-models, ambiguous tasks do not present difficulties, since the result of their solution is expressed in the form of intervals covering all solutions of the problem, and in the case where the problem has no solution, the calculation of the H-model notifies the user about this. Solving the inverse problems of investment design allows us to determine the conditions under which the project will be sufficiently effective or inefficient, and find solutions that can best meet the requirements of the project.

The ability to set the desired values of the resulting indicators. Conventional mathematical models that require a clear distinction between the parameters of the "input" and "output", do not allow you to directly specify the desired values of the resulting indicators. The computational process of H-models is different, it gives the opportunity to regulate the values of all the considered indicators, providing automatic coordination of the intervals of indicators with each other. As a result, you can set the value of any indicator of the investment project and observe the corresponding changes in other indicators.

The ability to analyze a large number of project options without busting them. The technology of N-models allows operating with the whole area of solutions, and not with individual variants of solutions, as it happens with traditional approaches. Any (including an infinite) set of "exact" project variants can be considered as one generalized project, in which the intervals of values of indicators contain all the values of the same indicators of "exact" options.

The ability "not to miss" any decision. The solution provided by the H-model automatically takes into account all the conditions laid down in the model. Without violation of these conditions, the process being modeled cannot go beyond the decision. This eliminates the danger of losing sight of any important solution.

Simplified project support. An important element of investment design is the project implementation plan. The plan of the "Night model" be- comes interval. Monitoring the implementation of the project, carried out on the basis of "accurate" planned requirements, requires constant revision of the planned indicators.

Actual values, indicators, predicted values require only a clarification of the plan, but do not require its revision.

The introduction in the $\mathrm{H}$-model of the actual values of the indicators for the completed part of the project allows you to:

- to narrow the width of the intervals of forecast indicators;

- to clarify the parameters of the still not completed part of the project;

- to identify the threat of critical situations for example, insufficient funding is found.

Fig. 2 shows a step-by-step refinement of the forecast characteristics of an investment project, possible when the actual values of indicators for the first, second and third year of the project are introduced into the $\mathrm{H}$-model (each new refinement corresponds to a darker and narrower area of the graph).

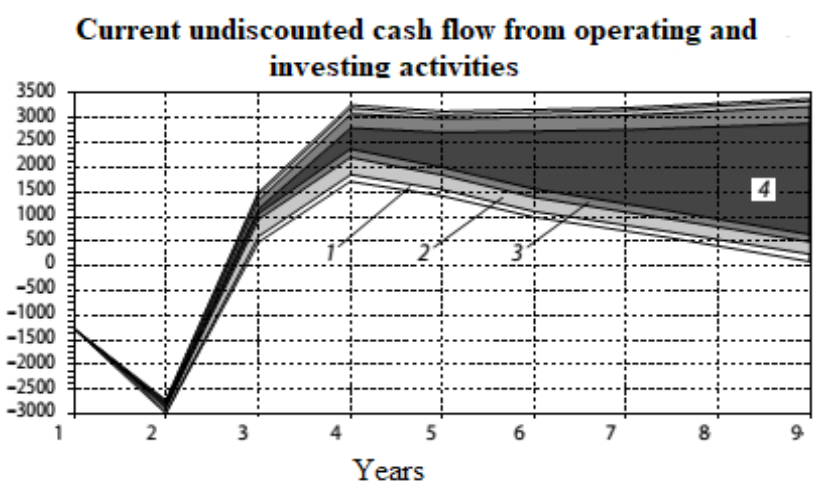

Accumulated undiscounted cash flow from operating and investing activities

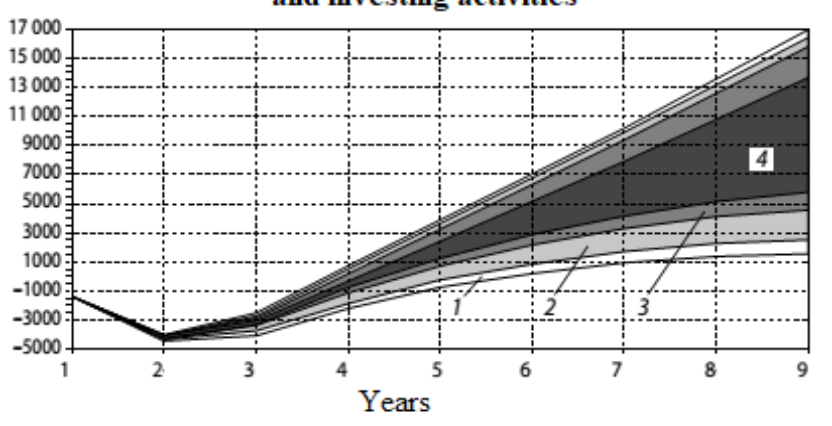

Fig. 2. Refinement in the process of project implementation of its cash flow, mln USD (1 - calculation according to data up to the $1^{\text {st }}$ year of implementation, 2 - calculation based on the results of the $1^{\text {st }}$ year of implementation,

3 - calculation based on the results of the $2^{\text {nd }}$ year of implementation, 4 - calculation based

on the results of the $3^{\text {rd }}$ year of implementation)

Source: developed by the author according to the data [3]

Thus, the use of $\mathrm{H}$-models makes it possible to take into account in project evaluation the influence of uncertainties on the factors affecting it and to predict possible areas of inefficiency of the project, which increases the reliability of results for investment project participants, improves the quality of monitoring project progress and reduces risks. 


\section{References:}

1. Narinyani A.S., Napreyenko V.G., Yurtaev A.V. Underdetermined Models - A NonConventional Approach to Mathematical Investigations of Economy // Informatsionnyie Tekhnologii (Information Tevhnologies). - 1999. No. 4 (in Russian).

2. Narinyani A.S., Napreyenko V.G. Development of Underdetermined Models for Economic Research Objectives: Proceedings of VIIth Artificial Intelligence Conference (23-27 October, 2000). - Pereslavl-Zalesskii (in Russian).

3. Narinyani A.S., Napreyenko V.G. An Experience in Underdetermined Economic Modeling: Proceedings of the IXth National Artificial Intelligence Conference with international participation. - M.: PhysMatLit Publishers, 2004. - V.1 (in Russian).

4. Nikonova I.A., Narinyani A.S., Shamgunov R.N., Napreyenko V.G. Evaluation of Investment Projects: Taking into Account Higher Uncertainty // Bankovskoye Delo (Bank Business). - 2009. - No. 10. - Pp. 64-68.

5. Napreyenko V.G. Synthesis of Multi-Parametric Economic Models Based on Incomplete and Inaccurate Data // Control and Modeling Problems in Complex Systems: Proceedings of the VIII International Conference CSCMP-2006. - Samara, 2006. 